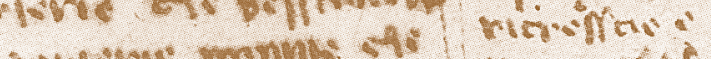

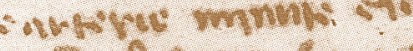

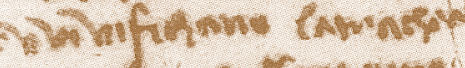

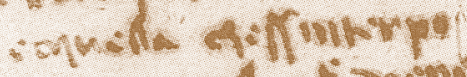
prome clis 2 pomo

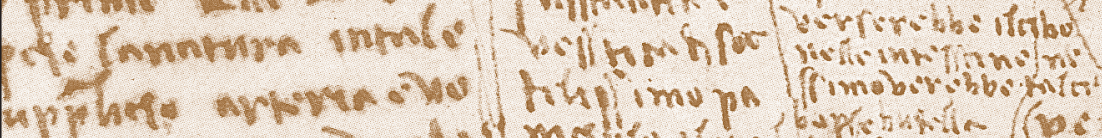

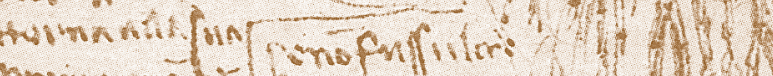

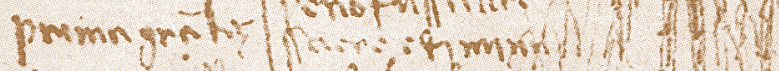

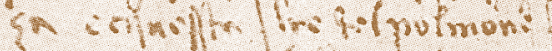

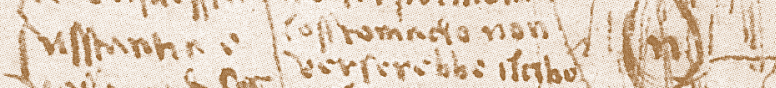
ISSN 1814-6910

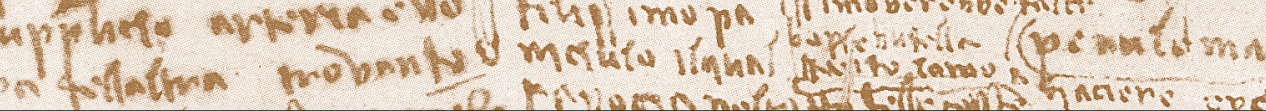
Kanнuчeckag

\title{
कuз4010249 кро800брамения
}

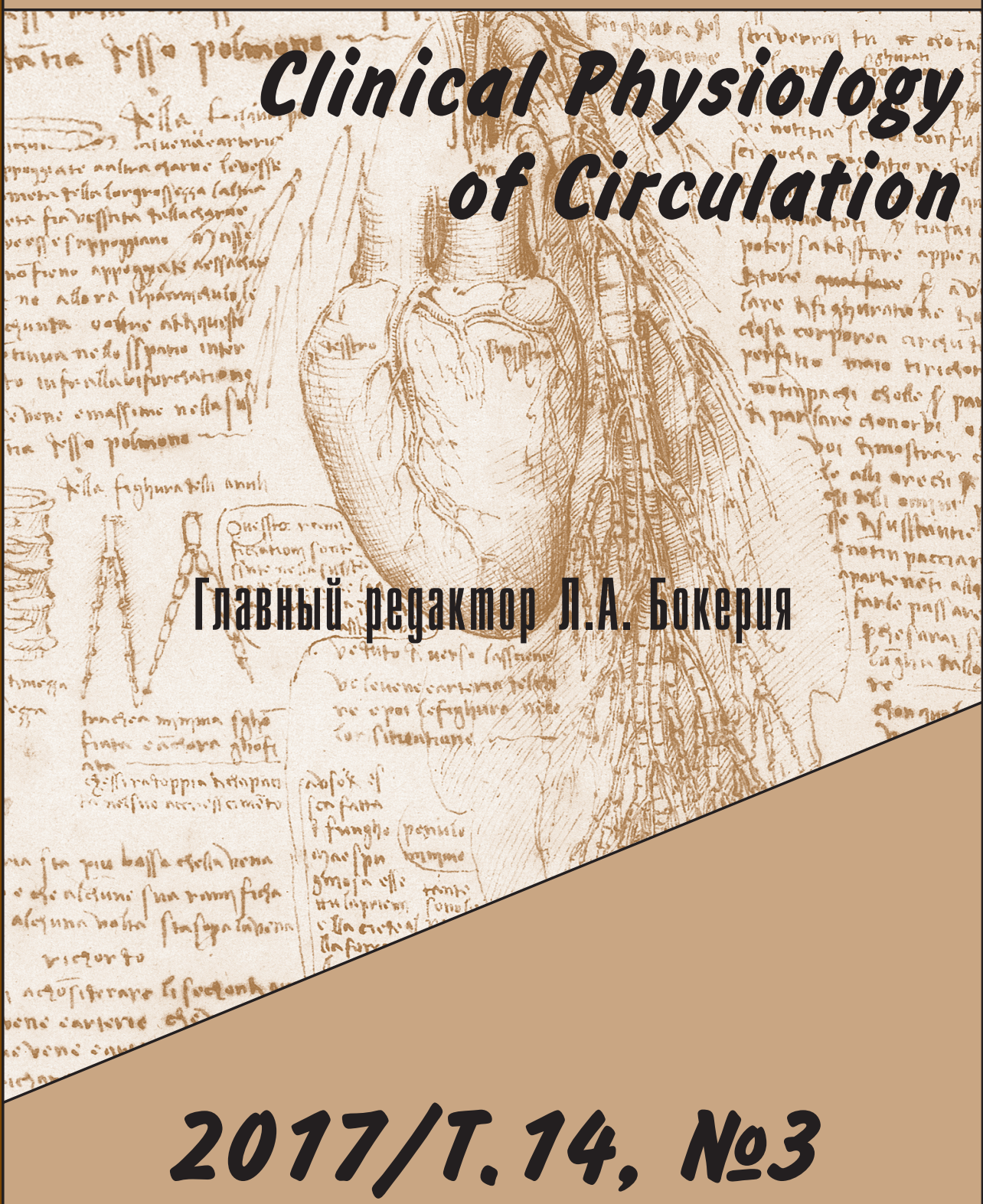

